\title{
SPECTROPHOTOMETRIC EVALUATION OF TOOTH COLOR IN CHILDREN WITH MIXED DENTITION
}

Karma Dişlenme Dönemindeki Çocuklarda Diş Renginin Spektrofotometrik Analizi

\author{
Şerife ÖZALP ${ }^{1}$, Şeyma Eslem VESKE ${ }^{2}$
}

$\begin{array}{lc}\text { Makale Kodu/Article Code } & : 466559 \\ \text { Makale Gönderilme Tarihi } & : 02.10 .2018 \\ \text { Kabul Tarihi } & : 03.12 .2018\end{array}$

\section{ABSTRACT}

Objective: In this study, the aim is to evaluate the shade of colors of the permanent maxillary central incisor, primary canine, primary first molar, primary second molar and permanent first molar teeth in individuals in mixed dentition stage using Vita Classic and Vitapan 3D Master scale, according to the $\mathrm{L}^{*}, \mathrm{a}^{*}, \mathrm{~b}^{*}$ color system.

Materials and Methods: Our study was performed on a total of 57 child patients between 7-12 years old. Color shade measurements were performed using VITA Easyshade Compact (Vita Zahnfabrik, Germany) spectrophotometry device; and CIE L*, a*, b* values according the Vita Classic and Vitapan 3D Master scale were recorded.

Results: In light of the obtained data, it was found that the $\mathrm{L}^{*}$ value of the permanent first molar was the lowest, the $L^{*}$ value of the primary canine was the highest $(p<0.001)$. The $a^{*}$ value of the central incisor was the lowest, whereas the $a^{*}$ value of the permanent first molar was the highest $(p<0.001)$. According to the data, when the $b^{*}$ values were compared, a statistically significant difference was detected only between the central incisor and primary first molar teeth $(\mathrm{p}=0.005)$.

Conclusion: It was found that in individuals at the mixed dentition stage, according to the Vita Classic scale, B2 tones were found more frequently in permanent teeth whereas A2 tones were more common in the primary teeth. C2 and D3 tones were not detected in both groups.

Key Words: Spectrophotometer, tooth color, primary teeth, mixed dentition
ÖZ

Amaç: Bu çalışmada, karışık dişlenme dönemindeki aynı bireye ait daimi maksiller santral kesici, süt kanin, süt birinci molar, süt ikinci molar ve daimi birinci molar dişlerin renklerinin Vita Classic ve Vitapan 3D Master skalası ile $L^{*}, a^{*}, b^{*}$ renk sistemine göre değerlendirilmesi amaçlanmıştır.

Gereç ve Yöntemler: Araştırmamız; 7-12 yaş arası toplam 57 çocuk hasta üzerinde yapılmıştır. Renk ölçümleri VITA Easyshade Compact (Vita Zahnfabrik, Germany) spektrofotometre cihazı ile yapılmış; Vita Classic ve Vitapan 3D Master skalasına göre renk ve CIE $L^{*}, a^{*}, b^{*}$ değerleri kaydedilmiştir.

Bulgular: Elde edilen veriler doğrultusunda daimi birinci molar dişin $\mathrm{L}^{*}$ değeri en düşük, süt kanin dişin $\mathrm{L}^{*}$ değerinin en yüksek olduğu saptanmıştır $(p<0,001)$. Santral kesici dişin $a^{*}$ değerinin en düşük, daimi birinci molar dişin $\mathrm{a}^{*}$ değerinin en yüksek olduğu belirlenmiştir $(p<0,001)$. Verilere göre $b^{*}$ değerleri karşılaştırıldığında ise sadece santral kesici ve süt birinci molar dişler arasında istatistiksel olarak anlamlı fark bulunmuştur $(\mathrm{p}=0,005)$.

Sonuçlar: Karışık dişlenme dönemindeki bireylerde Vita Classic skalasına göre daimi dişlerde B2 ve süt dişlerde A2 tonlar1 en fazla yüzdeliğe sahip olduğu bulunmuştur. C2 ve D3 tonları her iki grupta da hiç saptanmamıştır.

Anahtar Kelimeler: Spektrofotometre, diş rengi, süt dişi, karışık dişlenme

\footnotetext{
${ }^{1}$ Bezmialem Vakıf University, Faculty of Dentistry, Department of Pediatric Dentistry, Istanbul, Turkey.

${ }^{2}$ Private Dental Clinic, Istanbul, Turkey.
} 


\section{INTRODUCTION}

Color is a concept that arises when different wavelengths of light reach the retina of the eye, and perceived subjectively by the observer. ${ }^{1,2}$ The perceived color is affected by numerous factors including the personal color perception skills, light conditions, effect of the background, achromatism, differences between the two eyes, eye strain and other psychological factors; and in order for the color to be perceived, there should be an interaction between three factors. These are: light, object, and the observer. ${ }^{3,4}$

Color perception is subjective and thus differs from one person to another. This issue is of particular importance in dentistry. In dentistry, there are two different ways to perform color selection: visual measurement and color measurement devices. Visual measurement is subjective and is affected by the environmental factors. ${ }^{5}$ Color measurement devices are objective and provide numerical data to the user. ${ }^{6}$

Among the color systems developed to be able to define the color with standardized, numeric values are Munsell, Commission Internationale de l'Eclairage XYZ and Commision Internationale de l'Eclairage $\mathrm{L}^{*} \mathrm{a}^{*} \mathrm{~b}^{*}\left(\right.$ CIE L* $\left.\mathrm{a}^{*} \mathrm{~b}^{*}\right)$ systems. ${ }^{7}$

Munsell analyzes the color in three parameters: Hue, Chroma and Value. Hue is the name of the color, while chroma is the intensity of the color and value is the brightness of the color. ${ }^{8}$

In Commission Internationale de l'Eclairage (CIE L* $a^{*} b^{*}$ ) color system, there are 3 different axes to define color, which are $\mathrm{L}^{*}, \mathrm{a}^{*}$ and $\mathrm{b}^{* 2}$. $\mathrm{L}^{*}$ axis is the parameter that indicates the lightness, darkness, black/white or brightness of the color. In this parameter, the color closest to black has the value 0 , while the color closest to white has the value $100 \mathrm{~L}^{*}$. The axes $a^{*}$ and $b^{*}$ represent the chromatic values of the color. The horizontal axis $a^{*}$ indicates the redness (+) and greenness (-) of the color. If the value is positive, it indicates the degre of redness, if it is negative, it indicates the degree of greenness; whereas the horizontal axis $b^{*}$ indicates the yellowness $(+)$ and blueness (-) of the color. If the value is positive, it indicates the degree of yellowness, if it is negative, it indicates the degree of blueness. ${ }^{9,10}$

In the Commission Internationale de l'Eclairage (CIE XYZ) color system, the colors are referred to by the main tristimulus values. These are referred as $\mathrm{X}, \mathrm{Y}, \mathrm{Z}$ coordinates. $\mathrm{X}$ indicates the tristimulus values of red, $\mathrm{Y}$ of green, and $\mathrm{Z}$ of blue. ${ }^{11}$

Human teeth consists of soft tissue (pulpa), and the surrounding hard tissues comprising dentin and enamel, and the thickness of dentin and enamel are among the most important factors that determine the tooth color. Enamel and dentin thickness are different for primary and permanent teeth. ${ }^{12}$ Moreover, the size of the tubules, array direction, volume of the pulp chamber and the vitality of the pulp tissue are the other factors that determine tooth color. Color intensity of the dentine is lower due to the masking effect of the enamel. Since the thickness of the enamel is the lowest at the cervical line and highest at the incisor edge, the intensity is the highest at the cervical line due to the reflection of the dentine layer from below, and it decreases toward the incisor edge. ${ }^{13}$

Different from the permanent teeth, in primary teeth, the enamel contains more organic ingredients, is less mineralized and the distance between the enamel crystals is greater. Therefore, enamel layer of the primary teeth is more opaque than the permanent teeth. ${ }^{10,14}$ Compared with the size of the crowns of the primary teeth, the volume of the crown pulps of the primary teeth is greater than the volume of the crown pulps of the permanent teeth. Moreover, the decrease in the pulp chamber in permanent teeth upon the formation of tertiary dentin leads to a more yellowish appearance of 
the permanent teeth compared with the primary teeth. While the shade of the primary teeth are bluish white, the shade of the permanent teeth is yellowish. The more matte and bluish appearance of the primary teeth is a physiologic condition. ${ }^{15}$ Since the enamel in the primary teeth has a more opaque structure, the teeth have a white color that is called "milk color" and appear more bright. ${ }^{16}$

The method used to determine the tooth color must be easy to apply and reproducible. For color selection, two methods are used, which are visual measurement and color measurement devices. ${ }^{17}$ In dentistry, determining the color is mostly performed by comparing the permanent tooth color scales with the color of the tooth itself. ${ }^{18}$ Tooth color and the scale are subjectively compared under the same light source. When choosing the color, the interaction between the light source, object and the observer is important. The most important of these factors is the light source. The perceived color of an object is affected by the type of light the object is exposed to, its relationship with the colored objects at the environment and the experience of the observer. Because of this, a tooth can appear to have different colors under different circumstances. ${ }^{19}$ The most frequently used scales in the clinical studies are Vitapan Classic and Vita 3D Master scales. Vita Classic scale has 4 different color tones, A, B, $\mathrm{C}$ and $\mathrm{D}$, and comprises 16 colors with different color intensities in each group. Vita 3D Master scale is divided into 5 different color groups and comprises a total of 26 colors. In the scale, the numbers 1, 2, 3, 4 and 5 in front of the letters indicate the group number decreasing depending on the brightness; and the letters $\mathrm{M}, \mathrm{R}$ and $\mathrm{L}$ indicate the color hue. $\mathrm{L}$ indicates the yellow hue, $\mathrm{M}$ the middle of the yellow and red hues, and $\mathrm{R}$ indicates the red hue. The numbers $1 ; 2 ; 3 ; 1.5$ and 2.5 after the letters incidate the color intensity. ${ }^{20}$
Color measurement devices are spectrophotometer, colorimeter and digital cameras. ${ }^{21}$ Spectrophotometer measures the amount of visible energy reflected by an object and records it by identifying its value, chroma and hue values as a wavelength. ${ }^{22}$ It is a correct, reliable and easy-to-use device used to measure and compare color in dentistry. ${ }^{23}$

Colorimeter measures the transmittence and tristimulus values at the red, blue and green regions in the visible spectrum. It takes measurements according to the CIE Lab units $\left(L^{*}, a^{*}, b^{*}\right)$ and the obtained values can be mathematically analyzed. ${ }^{24}$

The working principle of the digital cameras is to analyze the obtained photograph pattern in the computer that the camera is connected to. After the image of the object of interest is obtained using the digital camera, the connected computer expresses these values in terms of CIE Lab units $\left(L^{*}, a^{*}, b^{*}\right){ }^{25}$

In the current study, using VITA Easyshade Compact (Vita Zahnfabrik, Germany) spectrophotometer, the data obtained after performing the color measurements of the permanent maxillary incisor, permanent primary molar and primary canine, primary first molar, primary second molar teeth without any structural and formal abnormality in the same individual in the healthy children aged between 7-12 years and at the mixed dentition stage were evaluated.

\section{MATERIALS AND METHODS}

This study was performed on a total of 57 children aged 7-12 years, without any decayed tooth or restoration in the mixed dentition stage, and with left or right permanent maxillary central incisor, primary canine, primary primary molar, primary second molar and permanent first molar teeth, who were admitted to the Department of Pedodontics in Bezmialem University, Faculty of Dentistry, after obtaining the approval of the clinical research ethics committee. Before the color 
measurement, it was checked whether fluoride gel or varnish was applied on the patient's teeth. Volunteering children participating in the study and their parents were informed about the study and its objective, and they were asked to sign an informed consent form. Before starting the color measurements, teeth which will be measured was brushed by the researcher without using any paste. Then, according to the company's instructions, color measurement was performed on the primary and permanent teeth at the same half of the maxilla using Vitapan 3D mastershade. All measurements were made by the same researcher, and to prevent cross-contamination, Vita Easyshade was disinfected after each measurements and for calibration, the probe was placed into the calibration area of the device that contains a ceramic chamber. The standard light necessary for measurement is generated by the lighting system at the probe and developed specifically for this purpose; thus, based on the company's recommendations, the light at the environment was ignored. The measurement was performed by selecting the single measurement option of the spectrophotometer and according to the instruction manual, by placing the probe in a way that enables it to contact horizontally with the central triad region at the vestibular surface of the teeth.

Measurement results were arranged according to both the Vitapan 3D Master color scale and the Vita Classic color scale, and the color distribution percentages were calculated according to these two color scales. CIE L*, $\mathrm{a}^{*}$ and $b^{*}$ values and color values determined according to the Vita Classic and Vitapan 3D Master scale were recorded. Measurement results were collected according to Vita Classic color scale and Vita 3D Master color scale. Color distribution was calculated according to thsi scale.

\section{RESULTS}

In light of the data obtained from the individuals, percent color distribution of permanent and primary teeth according to Vitapan Classical scale are given in Table 1. A2 was found more than the other colours both in permanent and primary teeth.

Table 1. Percent color distribution of permanent and primary teeth

\begin{tabular}{|c|c|l|c|}
\hline \multicolumn{2}{|c|}{ PERMANENT TEETH } & \multicolumn{2}{|c|}{ PRIMARY TEETH } \\
\hline $\mathbf{A 1}$ & 5.3 & $\mathbf{A 1}$ and A4 & 9.2 \\
\hline $\mathbf{A 2}$ & 21.1 & $\mathbf{A 2}$ & 21.5 \\
\hline $\mathbf{A 3}$ & 15.8 & $\mathbf{A 3}$ & 16.2 \\
\hline $\mathbf{A 3 . 5}$ & 1.8 & $\mathbf{A 3 . 5}$ and B2 & 4.8 \\
\hline $\mathbf{B 3}$ & 10.5 & $\mathbf{B 3}$ & 11.4 \\
\hline $\mathbf{C 1}$ & 7.0 & $\mathbf{C 1}$ and C3 & 5.3 \\
\hline $\mathbf{C 4}$ & 3.5 & $\mathbf{C 4}$ & 6.6 \\
\hline & & $\mathbf{D 4}$ & 5.7 \\
\hline
\end{tabular}

CIE $L^{*}, a^{*}, b^{*}$ values of the teeth of individuals are seen in Table 2. According to the Kruskal-Wallis Test, $\mathrm{L} *, \mathrm{a} *, \mathrm{~b} *$ values must have a $p<0.005$. A $p=0.005$ for $L^{*}$ and $a^{*}$ makes the value significant for us (Table 2).

Table 2. CIE L*, $a^{*}, b^{*}$ values of the teeth of individuals

Table 2. CIE L*, $\mathrm{a}^{*}, \mathrm{~b}^{*}$ values of the teeth of individuals
\begin{tabular}{|l|c|c|c|}
\hline & $\mathbf{L}^{*}$ & $\mathbf{a}^{*}$ & $\mathbf{b}^{*}$ \\
\hline Chi-Square & 92.671 & 91.827 & 14.669 \\
\hline $\mathbf{p}$ & 0.000 & 0.000 & 0.005 \\
\hline
\end{tabular}

To perform pairwise comparison, Dunn test was performed and the teeth were compared in terms of their $\mathrm{L}^{*}, \mathrm{a}^{*}$ and $\mathrm{b}^{*}$ values.

The groups were compared in terms of their $\mathrm{L}^{*}$ values and it was found that there is a statistical significance $(p<0.001)$. As a result of the Dunn test, a significant difference was detected between permanent molar-primary second molar, permanent first molar-central incisor, permanent first molar-primary first molar, permanent first molar-primary canine, primary canine-primary second molar, central incisor-primary canine, primary canineprimary first molar (Table 3 ). 
Table 3. Comparison between the groups in terms of their $\mathrm{L}^{*}$ values

\begin{tabular}{|l|c|c|c|c|c|}
\hline L* $^{*}$ & $\begin{array}{c}\text { Permanent } \\
\text { Central } \\
\text { Incisor }\end{array}$ & $\begin{array}{c}\text { Primary } \\
\text { Canine }\end{array}$ & $\begin{array}{c}\text { Primary } \\
\text { 1st Molar }\end{array}$ & $\begin{array}{c}\text { Primary } \\
\text { 2nd Molar }\end{array}$ & $\begin{array}{c}\text { Permanent } \\
\text { 1st Molar }\end{array}$ \\
\hline Median & 81.300 & 85.600 & 81.800 & 79.000 & 71.100 \\
\hline Minimum & 23.1 & 60.0 & 29.1 & 61.5 & 47.2 \\
\hline Maximum & 87.3 & 93.6 & 91.2 & 86.5 & 84.6 \\
\hline
\end{tabular}

- Median $\mathrm{L}^{*}$ value of the primary second molar > median $\mathrm{L}^{*}$ value of the permanent first molar

- The median $\mathrm{L}^{*}$ value of the central incisor > median $\mathrm{L}^{*}$ value of the permanent first molar

- The median $\mathrm{L} *$ value of the primary second molar > median $\mathrm{L}^{*}$ value of the permanent first molar

- The median $\mathrm{L}^{*}$ value of the primary canine > median $\mathrm{L}^{*}$ value of the permanent first molar

- The median $\mathrm{L} *$ value of the primary canine $>$ median $\mathrm{L} *$ value of the primary second molar

- The median $\mathrm{L} *$ value of the primary canine $>$ median $\mathrm{L} *$ value of the central incisor

- The median $\mathrm{L} *$ value of the primary canine> median $\mathrm{L}^{*}$ value of the primary first molar

When the groups were compared in terms of $a^{*}$ value, a statistical difference was detected $(\mathrm{p}<0.001)$. Dunn test was performed for pairwise comparisons and it was found that there is difference between central incisorprimary canine, central incisor-primary second molar, central incisor-primary first molar, central incisor- permanent first molar, primary canine-primary first molar, primary caninepermanent first molar (Table 4).

Table 4. Intergroup comparison in terms of the a * value
\begin{tabular}{|l|c|c|c|c|c|}
\hline \multicolumn{1}{|c}{$\mathbf{a}^{*}$} & $\begin{array}{c}\text { Permanent } \\
\text { Central } \\
\text { Incisor }\end{array}$ & $\begin{array}{c}\text { Primary } \\
\text { Canine }\end{array}$ & $\begin{array}{c}\text { Primary } \\
\text { 1st Molar }\end{array}$ & $\begin{array}{c}\text { Primary } \\
\text { 2nd Molar }\end{array}$ & $\begin{array}{c}\text { Permanent } \\
\text { 1st Molar }\end{array}$ \\
\hline Median & -0.900 & 0.300 & 1.500 & 1.200 & 1.600 \\
\hline Minimum & -2.8 & -1.5 & -0.6 & -0.7 & -1.0 \\
\hline Maximum & 5.2 & 13.1 & 11.9 & 19.3 & 7.6 \\
\hline
\end{tabular}

- Median $a^{*}$ value of the primary canine > median $a^{*}$ value of the central incisor

- Median $a^{*}$ value of the primary second molar

$>$ median $a^{*}$ value of the central incisor
- Median $a^{*}$ value of the primary first molar

$>$ median $a^{*}$ value of the central incisor

- Median $a^{*}$ value of the permanent first molar $>$ median $\mathrm{a}^{*}$ value of the central incisor

- Median $a^{*}$ value of the primary first molar $>$ median a * value of the primary canine

- Median $a^{*}$ value of the permanent first molar $>$ median a $*$ value of the primary canine

When the groups were compared in terms of $b^{*}$ value, it was found that there is a statistical difference $(p=0.005)$. Dunn test was performed for pairwise comparison and it was found that there is difference between central incisor-primary first molar teeth (Table 5).

Table 5. Intergroup comparison in terms of the $b^{*}$ value
\begin{tabular}{|l|c|c|c|c|c|}
\hline \multicolumn{1}{|c}{$\mathbf{b}^{*}$} & $\begin{array}{c}\text { Permanent } \\
\text { Central } \\
\text { Incisor }\end{array}$ & $\begin{array}{c}\text { Primary } \\
\text { Canine }\end{array}$ & $\begin{array}{c}\text { Primary } \\
\mathbf{1 .} \text { Molar }\end{array}$ & $\begin{array}{c}\text { Primary } \\
\mathbf{2 .} \text { Molar }\end{array}$ & $\begin{array}{c}\text { Permanent } \\
\mathbf{1 .} \text { Molar }\end{array}$ \\
\hline Median & 20.400 & 20.200 & 22.600 & 21.700 & 20.200 \\
\hline Minimum & 4.4 & 2.7 & 6.5 & 4.5 & 8.9 \\
\hline Maximum & 32.3 & 41.2 & 42.2 & 33.7 & 32.5 \\
\hline
\end{tabular}

- Median $b^{*}$ value of the primary first molar > median $b^{*}$ value of the central incisor

\section{DISCUSSION}

Human teeth is made up of enamel, dentin and soft tissues (pulp). Enamel and dentin layers are hard tissues that surround the soft tissue of the tooth. ${ }^{8,12}$ The thickness of these layers have important effects on tooth color. Difference between the primary teeth and permanent teeth in terms of the thickness of their enamel and dentin layers lead to a difference in color between the primary and permanent teeth. Moreover, thicker aprismatic layer of the primary teeth than the permanent teeth, larger pulp chamber in the primary teeth than the permanent teeth, less mineralized enamel and higher organic content of the primary teeth make primary teeth more opaque compared to the permanent teeth. Due to its high opacity, the enamel of the primary teeth tends to reflect the light. The amount of light reflected from and absorbed by the teeth depends on the thickness and transmittence of the dentin and enamel layer, and therefore these tissues play 
important role in determining the tooth color. Enamel tends to reflect the light. ${ }^{10,14}$

In this study on the analysis of color values of the teeth, using the spectrophotometer for color measurement, the amount of the visible energy in the light reflected by the tooty surface was measured and its wavelength was calculated.

Based on the results of the study, it was found that permanent first molar has a darker color than the permanent central, primary canine, primary first molar and primary second molar teeth. Since the $L^{*}$ value of the permanent molar tooth is low and a* value is high, the tooth appears darker and more red. In this study, it was found that the primary canine tooth has much lighter color than the other teeth whose color values were measured. This is because the $\mathrm{L}^{*}$ value of the primary canine is high and $\mathrm{a}^{*}$ value is low (Table 3 ). The negative $a^{*}$ value $(-0.900)$ of the central incisor suggests that this tooth is greenish in color (Table 4). Pop-Ciutrila et al. ${ }^{12}$ reported that the permanent molar tooth is darker than the permanent central and canine teeth. This is because the $\mathrm{L}^{*}$ value of the molar tooth is lower than the $\mathrm{L}^{*}$ value of the other teeth analyzed and the data obtained are concordant with Pop-Ciutrila et al. ${ }^{12}$

In the study by Savaş et al. ${ }^{26}$ in which the spectrophotometric color analysis of the permanent central teeth was performed based on their apical development, it was found that the most frequently observed tooth color in permanent central teeth is A2, and a statistically significant difference was detected between the dental root development and $\mathrm{L}^{*}$ values.

There is no significant difference in terms of the $b^{*}$ values between the teeth of the individuals other than that between the primary first molar and permanent central incisors. Primary first molar teeth are more yellowish than the central incisors (Table 5).
In the individuals participating in the study, percent values according to the Vitapan Classic scale were analyzed and B2 color was found more commonly in permanent teeth while A2 was more common in the primary teeth. The colors C2 and D3 could not be detected (Table 1). These findings are not concordant with the results of the study performed by R. Meera et al. ${ }^{27}$ According to the abovementioned study, the shade D2 has a higher percentage in the shade distribution of the primary teeth. ${ }^{27}$ In the study by Öngül et $a l^{20}$, the shade distribution of the permanent central teeth according to the Vita Classical scale was B2, C2 and C3. In the study by Y1lmaz et $a l^{28}$, it was reported that the shades A1 and B2 were more commonly observed in the permanent central teeth according to the Vita Classical scale.

When the shade of the primary and permanent teeth in children at the mixed dentition stage was evaluted, it was found that the primary canine tooth had a higher $\mathrm{L}^{*}$ value than the other teeth. It was found that the $\mathrm{a}^{*}$ value of the permanent first molar was higher than the other teeth. In the obtained data, a statistically significant difference was detected only between the primary first molar and central incisor in terms of the $b^{*}$ value.

\section{CONCLUSION}

In or study, it was found that the $\mathrm{L}^{*}$ value of the permanent first molar teeth was the lowest, and the $\mathrm{L}^{*}$ value of the primary canine tooth was the highest. While there is a significant difference between the teeth in terms of the $a^{*}$ value, there is a significant difference in terms of the $b^{*}$ value only between the primary first molar and permanent central incisor. While the distribution is mostly ranges between the shades A and B according to the Vita Classic scale, C2 and D3 could not be detected.

\section{REFERENCES}

1. van der Burgt $\mathrm{TP}$, ten Bosch JJ, Borsboom PC, Kortsmit WJ. A comparison of 
new and conventional methods for quantification of tooth color. J Prosthet Dent 1990; 63: 155-162.

2. Bridgeman I. The nature of light and its interaction with matter. In: McDonald R, ed. Color Physics for Industry. Huddersfield, UK: H Charlesworth and Co; 1987: 1-34

3. Chu SJ, Devigus A, Mieleszko A. Fundamentals of color shade matching and communication in esthetic dentistry. Quintessence Pub Co Inc, 2004. p. 14-6.

4. Sarıkaya I, Güler AU. Diş Hekimliği Uygulamalarında Renk Kavramı.Turkiye Klinikleri J Dental 118 Sci 2009; 15(2): 11829.

5. Sproull RC. Color matching in dentistry. Part II: practical applications fort he organization of color. 1973. J Prosthet Dent 2001; 86: 458-464.

6. McLaren K. Colour space, colour scales, and colour difference. In: McDonald R, ed. Color Physics for Industry. Huddersfield, UK: H Charlesworth and Co;1987: 97-115.

7. Turgut S, Bağış B. Color in dentistry and color measuring methods. J Dent Fac Atatürk Uni 2012 Supplement:5: 65-75.

8. Paravina RD, Powers JM. Esthetic color training in dentistry. St. Louis: Elsevier Mosby, 2004: 26, 139, 142.

9. Kuehni R. The early developement of the Munsell system. Color Research and Application 2002; 27: 20-7.

10. Rosenstiel SF, Land MF, Fujimoto J. Contemporary fixed prosthodontics. 4th Ed. St. Louis: Mosby, 2006: 709-726.

11. Sharma A. Understanding Color Management Thomson Delmar Learning, Amerika 2004, ISBN: 1-4018-1447-6

12. Pop-Ciutrila I-S, Colosı HA, Dudea D, Badea ME. Spectrophotometric color evaluation of permanent incisors, canines and molars. A cross-sectional clinical study. Clujul Medical 2015 Vol. 88;4: 537-544.

13. Ten Bosch JJ, Coops JC. Tooth color and reflectance as related to light scatterinng and enamel hardness. J Dent Res 1995; 74: 374-80

14. Dozic A, Kleverlaan CJ, Aartman IHA, Feilzer AJ. Relation in color of three regions of vital human incisors. 2004; 20: 832-838

15. Fondriest J. Shade: Matching in Restorative Dentistry. The Science and Strategies. Int J Periodontics Restorative Dent 2003; 23: 467-479.

16. Altan G. Pedodonti. İstanbul: İstanbul Üniversitesi Rektörlüğü Basımevi ve Film Merkezi, 1994

17. Bilmeyer FW, Salzman M. Principles of color technology 2nd ed. New York: John Wiley: 1981. P. 1-100.

18. Van der Burgt $\mathrm{TP}$, ten Borsch JJ, Borsboom PC, Kortsmit WJ. A comprison of new and conventional methods for quantification of tooth color. J Prosthet Dent 1990; 63: 155-62.

19. Rosenstiel SF, Land MF, Fujimoto j. Contemporary fixed prosthodontics, 4 th ed. St Louis; The CF Mosby Company: 2001. P. 70939.

20. Öngül $D$, Çelik B, İlbey $D$, Şermet B. Investigation of tooth color distribution of young patients of Turkish society. J Dent Fac İstanbul Uni. 2013. p. 30-40.

21. R. Meera, BDS, Joshua Shieh, BDS, M. S. Muthu, MDS, PhD. IN vivo evaluation of the color of anterior primary teeth. J Dent Child 2011; 78(3): 154-8.

22. Paul S, Peter A, Pietrobon N, Hammenle $\mathrm{CH}$. Visual and spectrophotometric shade analysis of human teeth. J Dent Res 2002; 81: $578-82$.

23. Paul SJ, Peter A, Rodoni L, Pietrobon N. Conventional visual vs spectrophotometric shade taking for porcelein-fused-to-metal 
crowns: a clinical comparison. International Journal of Periodontics and Restorative Dentistry 2004; 24: 222-31.

24. Garber DA, Goldstein RE, Feinmann RA. Porcelein laminate veneers. Quintessence Publishing Co. Inc., Chicago, 1998.

25. Wee Ag, Lindsey DT, Kuo S, Johnston WM. Color accuracy of commercial digital cameras for use in dentistry. Dent Mater 2006; 22(6): 553-9. 18

26. S. Savaş, F. Kavrık, B. Yasa, E. Kucukyılmaz. Spectrophotometric color analysis of maxillary permanent central incisors in a pediatric population: a preliminary study. International Journal of Pediatric Dentistry 2016.

27. Meera R, Shieh J, Muthu MS. In vivo evaluation of the color of anterior primary teeth. Journal of Dentistry 2011; 78(3): 154158.
28. Yavaş SK, Şeker E, Ozan O, Meriç G, Ulusoy MM. Evaluation of the naturel tooth color of young Turkish population in Northern Cyprus: A pilot study. Cumhuriyet Dent J 2011; 14(3): P. 164-174

\section{Corresponding Author}

Şerife ÖZALP

Bezmialem Vakıf University

Faculty of Dentistry

Department of Pediatric Dentistry

Adnan Menderes Bulvarı (Vatan Cad.)

P.K.: 34093

Fatih / Istanbul

Phone : +902125232288

Fax : : +902126217578

E-Mail : serifeozalp@gmail.com 